\title{
PENGEMBANGAN PEMBELAJARAN BERBASIS NILAI-NILAI BUDAYA YOGYAKARTA DI SEKOLAH DASAR
}

\author{
Anik Ghufron, C. Asri Budiningsih, dan Hidayati \\ Fakultas Ilmu Pendidikan Universitas Negeri Yogyakarta \\ email: Anikghufron@uny.ac.id
}

\begin{abstract}
Abstrak: Penelitian ini bertujuan mengembangkan model pembelajaran berbasis nilai-nilai budaya Yogyakarta yang relevan di sekolah dasar. Penelitian menggunakan pendekatan penelitian dan pengembangan model Borg dan Gall. Subjek penelitian adalah para guru dan siswa sekolah dasar tempat penelitian. Teknik pengumpulan data menggunakan observasi dan wawancara. Teknik analisis data dengan teknik deskriptif kualitatif. Temuan penelitian dapat dipaparkan sebagai berikut. Pertama, model pembelajaran yang relevan digunakan untuk penanaman nilai-nilai budaya Yogyakarta adalah model pembelajaran non direktif versi Carl Rogers. Kedua, modifikasi dan penyesuaian model pembelajaran ini dilakukan agar dapat digunakan untuk menanamkan nilai-nilai budaya Yogyakarta di sekolah dasar terutama yang berkaitan dengan format rencana pelaksanaan pembelajaran (RPP). Ketiga, para guru mampu melaksanakan pembelajaran menggunakan model non direktif untuk penanaman nilai-nilai budaya Yogyakarta sesuai dengan kurikulum yang berlaku di sekolah dasar dengan tetap memperhatikan kebijakan Pemda DIY tentang pengembangan kurikulum berbasis budaya Yogyakarta.
\end{abstract}

Kata kunci: nilai-nilai budaya Yogyakarta, sekolah dasar, pembelajaran

\section{DEVELOPING INSTRUCTIONAL MODELBASED ON CULTURAL VALUES OF YOGYAKARTA AT PRIMARY SCHOOL}

\begin{abstract}
This study seeks to develop a primary schoolinstructional model based on cultural values of Yogyakarta. Research and development model by the Borg and Gall was adopted. Subjects of the research were primary schoolteachers and students. Data were collected through observations and interviews. Data were analyzed using descriptive qualitative methods. The results show the followings. Firstly, the instructional model whichfits the cultural values of Yogyakarta is Carl Rogers's non directive model. Secondly, the instructional model should be modified in order to effectively foster thecultural values of Yogyakarta at primary school, especially when dealing with lesson planning. Thirdly, the teachers are able to apply this non directive instructional model to foster cultural values of Yogyakarta while paying attention to the official curriculum and to the local policy of curriculum development based on the cultural values of Yogyakarta.
\end{abstract}

Keywords: cultural values of Yogyakarta, primary school, instruction

\section{PENDAHULUAN}

Pembelajaran dikatakan berhasil manakala kegiatan yang berlangsung di sekolah itu mampu memfasilitasi peserta didik dalam proses transfer of value dalam konteks pembentukan karakter bangsa (nation character building) sebagaimana yang tercantum dalam kurikulum resmi. Namun demikian, tidak semua guru mampu mengembangkan dan melaksanakan pembelajaran tersebut. Padahal, kegiatan pembelajaran merupakan faktor determinan bagi keberhasilan dan mutu lulusan.

Mengapa masih ada guru yang belum mampu mengembangkan dan melaksanakan pembelajaran yang mampu memfasilitasi peserta didik tumbuh kembang nilai-nilai karakter bangsa? Salah satu sebabnya adalah referensi guru tentang model-model pembelajaran berbasis pendidikan karakter masih terbatas. Model-model pembelajaran yang digunakan guru masih sebatas pada model-model pembelajaran verbalistik. Akibatnya, pemahaman peserta didik kurang komprehensif dan tak menyentuh esensi moral yang berlaku di masyarakat.

Realitas ini menunjukkan bahwa institusi pendidikan belum berhasil dalam proses penyiapan lulusan bermoral dan berkarakter bangsa. Beberapa kasus yang terjadi pada akhir-akhir ini 
di sekitar kita menunjukkan adanya krisis moral di kalangan peserta didik, antara lain; pesta miras di kalangan pelajar, tawuran antarpelajar, dan pelecehan seksual.

Kasus ini tidak hanya terjadi pada satu daerah atau masyarakat tertentu saja, tetapi sudah menggejala di seantero nusantara. Di Daerah Istimewa Yogyakarta, kasus-kasus tersebut juga sudah ada tanda-tandanya. Sementara itu, agar bisa memenangi kompetisi di berbagai bidang kehidupan mensyaratkan tersedianya SDM cerdas, cendikia, dan bermoral.

Kita menyadari bahwa Pemerintah telah melakukan upaya-upaya untuk meningkatkan kemampuan guru dalam penyelenggarakan kegiatan pembelajaran yang lebih bermutu, khususnya yang berkaitan dengan pengembangan model-model pembelajaran berbasis pendidikan karakter di sekolah. Misalnya, Pemerintah Daerah Istimewa Yogyakarta telah menerbitkan Peraturan Provinsi Daerah Istimewa Yogyakarta, nomor 5 tahun 2011 tentang Pengelolaan dan Penyelenggaraan Pendidikan berbasis budaya. Namun demikian, hasilnya belum cukup menggembirakan.

Demikian pula, dengan masih adanya kebijakan tentang penerapan pembelajaran berbasis pendidikan karakter di sekolah semakin meyakinkan kita bahwa pembelajaran berbasis pendidikan karakter relevan diterapkan dalam sistem pendidikan nasional (sisdiknas). Walaupun harus diakui masih ada sekelompok orang yang meragukan efektivitas model pembelajaran berbasis pendidikan karakter dalam konteks reformasi pendidikan untuk mengembangkan SDM berkarakter bangsa Indonesia dan berkualitas yang siap berkiprah secara berjaya dalam dunia ipteks yang mengglobal.

Apa yang dimaksud dengan pembelajaran berbasis nilai-nilai budaya Yogyakarta? Pembelajaran berbasis nilai-nilai budaya adalah model pembelajaran yang digunakan guru untuk memfasilitasi peserta didik dalam menguasai seperangkat rumusan kompetensi, dengan mengedepankan dan mengacu pada nilai-nilai budaya yang berlaku di masyarakat Yogyakarta.

Dengan batasan yang demikian, para pengelola dan penyelenggara pembelajaran di sekolah perlu memahami nilai-nilai budaya, baik sebagai isi materi maupun pendekatan pembelajaran. Hal ini perlu dilakukan karena kesalahan atau perbedaan makna nilai-nilai budaya akan berpengaruh terhadap ketercapaian tujuan pendidikan nasional yang mengandung nilai-nilai budaya.
Nilai-nilai budaya apa saja yang perlu dijadikan bahan ajar dan pendekatan pembelajaran? Berdasarkan Peraturan Provinsi Daerah Istimewa Yogyakarta, nomor 5 tahun 2011 tentang pengelolaan dan penyelenggaraan pendidikan berbasis budaya, nilai-nilai budaya Yogyakarta memuat; nilai-nilai luhur (spiritual, personal - moral, sosial, dan nasionalisme Yogyakarta), artefak (sastra pertunjukan, lukis, busana, kriya, arsitektur, dan boga), dan adat (sosial - jati diri, ekonomi - walfare, dan politik - kekuasaan), yang berkembang, berlaku, diakui, diyakini, dan disepakati untuk dilaksanakan oleh setiap warga masyarakat Yogyakarta. Nilai-nilai tersebut, menurut Ekowarni (2010) tak lain adalah nilai-nilai luhur (supreme values) yang merupakan pedoman hidup (guiding principles) yang digunakan untuk mencapai derajat kemanusiaan yang lebih tinggi, hidup yang lebih bermanfaat, kedamaian dan kebahagiaan.

Dalam konteks implementasi KTSP, sesungguhnya, model pembelajaran ini sangat relevan dipakai. KTSP yang dikembangkan dan mengacu pada rumusan kompetensi lulusan memerlukan model implementasi kurikulum yang mampu memfasilitasi peserta didik dalam penguasaan kompetensi. Dalam pandangan Sanjaya (2005:81-82) pembelajaran dalam konteks kurikulum berbasis kompetensi perlu memperhatikan prinsip-prinsip; proses pembelajaran adalah membentuk kreasi lingkungan yang dapat membentuk atau mengubah struktur kognitif peserta didik, berhubungan dengan tipe pengetahuan yang harus dipelajari, dan harus melibatkan peran lingkungan sosial. Di sini, yang hendak diwujudkan adalah lulusan yang kompeten di bidangnya dan berkarakter bangsa.

Ada beberapa ciri khas model pembelajaran berbasis nilai-nilai budaya yang membedakan dengan model pembelajaran lainnya. Pertama, sasaran pembelajaran adalah peserta menguasai domain yang ada di dalam rumusan kompetensi dan nilai-nilai karakter yang terkandung di dalamnya. Kedua, aktivitas-aktivitas pembelajaran ditujukan untuk memfasilitasi peserta didik memperoleh kompetensi yang terumuskan dalam kurikulum yang berlaku, dengan tetap mengedepankan tindakan-tindakan pengembangan nilai-nilai karakter bangsa. Ketiga, materi pembelajaran diorganisir secara terpadu (integrated) dengan dimensi nilai-nilai karakter bangsa yang terkait. Keempat, lingkungan pembelajaran ditata secara alamiah. Artinya, peserta didik diberi kesempatan 
belajar untuk memperoleh pengalaman belajar nyata di masyarakat yang berkaitan dengan nilainilai luhur yang berkembang kemasyarakatan. Pengalaman nyata di masyarakat sangat efektif daripada pengetahuan instant yang berkembang dalam kelas yang serba terisolir.

Bertitik tolak dari paparan di atas, peneliti bermaksud melakukan penelitian dengan fokus pada pengembangan pembelajaran berbasis nilainilai budaya Yogyakarta di sekolah dasar. Dengan demikian, rumusan masalah yang diajukan adalah "Bagaimanakah mengembangkan pembelajaran berbasis nilai-nilai budaya Yogyakarta di sekolah dasar?"

Fokus penelitian ini adalah pengembangan model pembelajaran berbasis nilai-nilai budaya Yogyakarta di sekolah dasar. Secara khusus, masalah penelitian yang ingin dijawab melalui penelitian ini adalah "bagaimana mengembangkan model pembelajaran berbasis nilai-nilai budaya Yogyakarta di sekolah dasar secara efektif?"

Penelitian ini bertujuan untuk mengembangkan pembelajaran berbasis nilia-nilai budaya Yogyakarta di sekolah dasar. Hasil penelitian ini diharapkan memberi kemanfaatan bagi upaya peningkatan mutu pembelajaran dan kompetensi guru dalam kegiatan pembelajaran, yang tidak sekedar sebagai kegiatan transfer of knowledge, tetapi juga sebagai kegiatan transfer of value.

\section{METODE}

Penelitian ini menggunakan model penelitian dan pengembangan (research and development) versi Borg dan Gall. Borg dan Gall (1983:772) mengatakan "educational research dan development $(R \& D)$ is a process used to develop and validate educational production". Dengan pengertian tersebut maka serangkaian langkah penelitian dan pengembangan dilakukan secara siklus, yang mana pada setiap langkah yang dikembangkan selalu mengacu pada hasil langkah sebelumnya dan pada akhirnya diperoleh suatu produk pendidikan yang baru.

Pada dasarnya, langkah-langkah penelitian dan pengembangan ini meliputi sepuluh langkah, namun secara garis besar dapat diringkas menjadi empat langkah utama yang dipaparkan pada gambar 1 sebagai berikut.

Berdasarkan gambar 1, dapat dikatakan bahwa model penelitian dan pengembangan ini memuat langkah-langkah sebagai berikut.

Pertama, studi pendahuluan yaitu melakukan identifikasi nilai-nilai budaya Yogyakarta yang akan diberikan kepada peserta didik melalui studi dokumentasi terhadap berbagai peraturan pemerintah Daerah Istimewa Yogyakarta yang berkaitan dengan pengelolaan penyelenggaraan pendidikan berbasis budaya Yogyakarta. Hasil kegiatan ini diharapkan dapat dijadikan titik tolak pengembangan model pembelajaran berbasis nilai-nilai budaya Yogyakarta.

\section{RANCANGAN PENELITIAN}

\section{Pendahuluan}

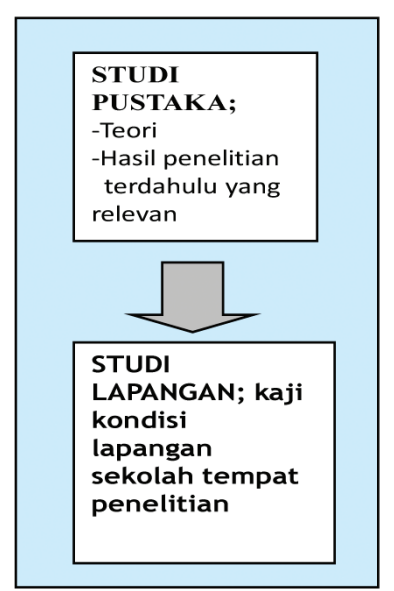

Pengembangan

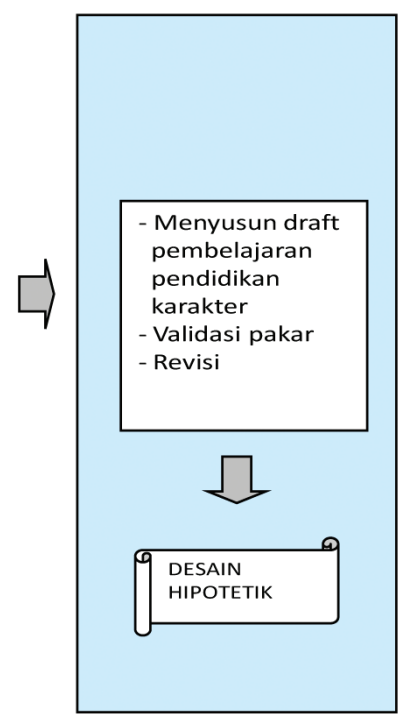

Uji lapangan

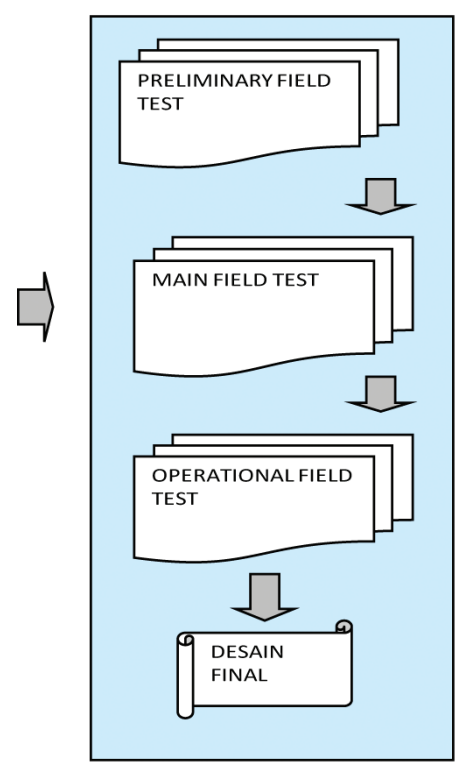

Diseminasi

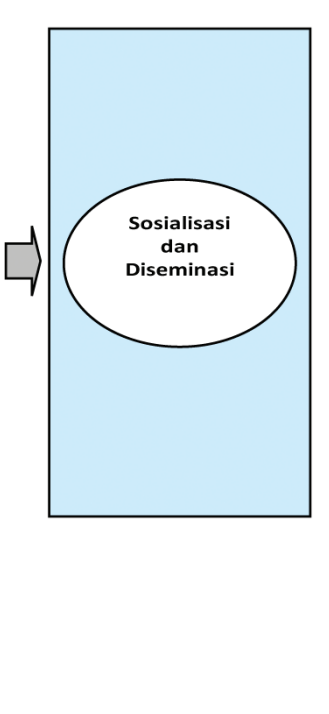

Gambar 1 Rancangan Penelitian 
Kedua, mengembangkan model pembelajaran non direktif yang dipandang relevan digunakan untuk penanaman nilai-nilai budaya Yogyakarta dengan cara melakukan diskusi dengan Kepala Sekolah dan guru-guru di Sekolah Dasar Negeri Giwangan Yogyakarta, dan selanjutnya draft hasil pengembangan model pembelajaran dinilai oleh pakar pembelajaran sebelum diujicobakan. Hasil kegiatan pada tahap ini adalah panduan pembelajaran yang dikemas dalam bentuk rancangan pelaksanaan pembelajaran (RPP) berbasis nilainilai budaya Yogyakarta.

Ketiga, uji coba kelayakan terhadap model pembelajaran yang relevan untuk penanaman nilai-nilai budaya Yogyakarta di sekolah dasar oleh tiga guru Sekolah Dasar Negeri Giwangan Yogyakarta. Kegiatan-kegiatan yang dilakukan yaitu mengimplementasikan rancangan model pembelajaran non direktif berbasis nilai-nilai budaya Yogyakarta, evaluasi, revisi dan penyempurnaan model.

Keempat, validasi produk model pembelajaran berbasis nilai-nilai budaya Yogyakarta dalam bentuk eksperimen. Melalui eksperimen ini akan diperoleh indeks efektivitas penggunaan model pembelajaran berbasis nilai-nilai budaya Yogyakarta terhadap peningkatan mutu pembelajaran lima mata pelajaran pokok di sekolah dasar.

Kelima, penyusunan panduan pembelajaran dan melakukan sosialisasi dan diseminasi panduan model pembelajaran berbasis nilai-nilai budaya Yogyakarta kepada sejumlah sekolah dasar. Kegiatan ini dilakukan secara bertahap dan dimungkinkan pada skala propinsi Daerah Istimewa Yogyakarta.

Dari kelima tahapan di atas, pada penelitian ini memfokuskan pada tiga kegiatan, yaitu identifikasi nilai-nilai budaya Yogyakarta yang akan diberikan kepada peserta didik, pengembangan model pembelajaran non direktif yang dipandang relevan digunakan untuk penanaman nilai-nilai budaya Yogyakarta, dan uji kelayakan terhadap model pembelajaran yang relevan untuk penanaman nilai-nilai budaya Yogyakarta di sekolah dasar oleh tiga guru Sekolah Dasar Negeri Giwangan Yogyakarta.

Penelitian ini menggunakan responden sebagai subyek penelitian adalah para guru pada lima mata pelajaran pokok di sekolah dasar. Sesuai dengan model penelitian yang digunakan, subyek penelitian diambil secara purposive, tetapi tetap memperhatikan keterwakilan sekolah dasar (mutu pengelolaan sekolah) dalam kategori baik, sedang, dan rendah).

Teknik pengumpulan data yang digunakan adalah panduan observasi pembelajaran dan wawancara. Panduan observasi untuk mengetahui kinerja guru dalam melaksanakan kegiatan pembelajaran berbasis nilai-nilai budaya Yogyakarta. Wawancara, untuk klarifikasi hasil observasi. Teknik analisis data yang digunakan adalah analisis data kualitatif. Teknik analisis kualitatif untuk mengetahui kelayakan model pembelajaran berbasis nilai-nilai budaya Yogyakarta.

\section{HASIL DAN PEMBAHASAN Identifikasi Nilai-nilai Budaya Yogyakarta}

Langkah pertama yang perlu dilakukan untuk mengembangkan model pembelajaran yang relevan dalam penanaman nilai-nilai budaya Yogyakarta di sekolah dasar adalah mengidentifikasi nilai-nilai budaya Yogyakarta. Identifikasi ini dilakukan mengacu pada Peraturan Gubernur Daerah Istimewa Yogyakarta Nomor 66 Tahun 2013 tentang Kurikulum Pendidikan Berbasis Budaya, khususnya yang berlaku di sekolah dasar.

Berdasarkan kajian dan hasil diskusi dengan Kepala Sekolah SD Negeri Giwangan Yogyakarta diperoleh deskripsi nilai-nilai budaya Yogyakarta yang layak diajarkan kepada peserta didik. Muatan nilai-nilai budaya yang sangat lekat dengan kehidupan masyarakat Jawa dan diyakini bisa membawa ketentraman dalam hidupnya terdiri dari budi pekerti luhur (budi luhur), hasil karya atau budi daya manusia (artefak) dan adat kebiasaan masyarakat yang memiliki nilai strategis mewarnai pendidikan di Daerah Istimewa Yogyakarta dan perlu diberikan kepada peserta didik di sekolah dasar sebagai berikut.

Pertama, nilai-nilai luhur yang terumuskan dalam berbagai ungkapan yang perlu diberikan peserta didik di sekolah dasar, antara lain; memayuhayuning bawana, lembah manah, golong gilig manunggaling kawula gusti, nyawiji lahir batine, duwe greget kanggo tumindak lan makarya kang becik, duwe sengguh sing becikyaiku tanggap trengginas ngrampungi karya (selalu mengutamakan pelayanan yang baik dan optimal), ora mingkuh tegese tan ngoncati karya nandyan angel nrampungi kapara nemoni bebendu, luwih becik mikul angkring sinambi ura-ura tinimbang numpak montor karo mrebes mili, nglurug tanpa bala menang tanpa ngasorake, dan cepet tanpa ndhisiki banter tanpa nglancangi. 
Kedua, artefak berupa karya seni dan karya lainnya yang sarat dengan nilai-nilai luhur, termasuk di dalamnya arsitektur fisik lokal dengan keharmonisan, keindahan, kekokohan yang sekaligus mencerminkan aspek-aspek lain dari pranata sosial. Secara garis besar artefak memuat jenis-jenis karya seni-budaya berbentuk artefak produk budaya, seni sastra dan bahasa, dan adat istiadat.

Artefak produk budaya terdiri atas: gamelan gaya Yogya (rancak pendek), wayang orang gaya Yogya, omah dhom, batik grodha, tari golek menak, reyog dhodhog, wayang gagrag Ngayogya, wayang golek menak, wayang lancil, wayang ukur, wayang thenklung, kethoprak, tayub, sronthul (srandhul), kethek ogleng, gejog lesung, jeg-jegan, jlumpet, gobag sodor, lepetan, sepak sekong, kipo, jadah tempe, bakpya, geplak, gudheg, growol, gebleg, slondhok renteng, thiwul ayu, surjan, dan kebayak kuthubaru.

Artefak produk seni sastra dan bahasa, meliputi: (1) bahasa Jawa yang merupakan bahasa resmi dari suku Jawa; (2) aksara yang bersumber dari aksara Jawa yang berjumlah 20 aksara tersebut menjadi inspirasi pembelajaran budaya Jawa yang dapat digunakan mempelajari berbagai ilmu pengetahuan baik lokal, nasional, regional, global bahkan internasional; (3) busana atau pakaian dalam budaya Jawa sangat sakral dan tinggi sekali nilainya; (4) boga atau makanan ada yang menyebut kuliner adalah sarana hidup yang dimaknai sebagai penghidupan (panguripan) dalam budaya jawa adalah makanan sebagai sarana untuk hidup tumbuh dan berkembang atau bertambah besar seseorang yang berarti sarana hidup itu harus makan kalau tidak makan mati (srana urip kuwi kudu mangan yen ora mangan mati) supaya bisa hidup harus mencari makan (ngupa boga) tetapi makanan yang dicari harus yang halal, bermanfaat bagi kesehatan dan agama; dan (5) tembang atau lagu dalam budaya jawa diwujudkan dalam rangkaian tembang Jawa untuk menyampaikan beberapa pesan kepada masyarakat, siswa, kekasih, orang tua dan orang lain yang berisi pendidikan atau pesan kebaikan, bakti pada orang tua, bahkan pesan asmara kepada sang kekasih.

Adat istiadat, terdiri atas grebeg, tumplak wajik, rasulan, mubeng beteng, tingkep (mitoni), puputan, bekakak, mbah bergas (syukur bumi), kirab Pusaka Kyai Tunggul Wulung, tedhak siten, dan tumplak punjen.
Nilai-nilai budaya Yogyakarta tersebut yang akan diintegrasikan ke dalam setiap pokok bahasan yang relevan. Sesuai Peraturan Gubernur Daerah Istimewa Yogyakarta nomor 66 tahun 2013 tentang Kurikulum Pendidikan Berbasis Budaya, para guru diharapkan mengintegrasikan nilai-nilai budaya Yogyakarta tersebut ke dalam setiap pokok bahasan pada mata pelajaran yang relevan.

\section{Pengembangan Model Pembelajaran}

Mengacu pada Peraturan Gubernur Daerah Istimewa Yogyakarta Nomor 66 Tahun 2013 tentang Kurikulum Pendidikan Berbasis Budaya bahwa tujuan dari kegiatan pengembangan kurikulum berbasis budaya Yogyakarta adalah memperkaya atau memberi nilai tambah "ruh budaya", baik isi maupun pelaksanaanya maka model pembelajaran yang relevan digunakan adalah model pembelajaran non direktif dari Carl Rogers. Selanjutnya, agar model pembelajaran ini memadai dan layak digunakan maka model tersebut perlu dilakukan modifikasi terhadap beberapa aspek dan langkah pembelajarannya sesuai dengan kebijakan kurikulum yang berlaku. Oleh karena itu, sebelum model pembelajaran ini diterapkan untuk penanaman nilai-nilai budaya Yogyakarta di sekolah dasar diperlukan kajiankajian dalam bentuk diskusi dengan para guru, kepala sekolah, dan ahli pembelajaran.

Model pembelajaran nondirektif berasal dari konsep nondirective counseling. Model pembelajaran ini memusatkan perhatian pada upaya memfasilitasi peserta didik dalam kegiatan belajarnya. Untuk itu, guru diharapkan mampu berperan sebagai fasilitator dan membantu peserta didik memperoleh pengalaman belajar masingmasing sesuai keinginan peserta didik.

Secara umum, karakteristik model pembelajaran ini dapat dilihat dalam Tabel 1.

Selanjutnya, sebelum dilakukan uji coba model peneliti meminta ahli pembelajaran untuk melakukan penilaian terhadap draft model pembelajaran tersebut dilihat dari sisi kelayakan teoritik dan metodologik. Penilaian model pembelajaran difokuskan pada rumusan tujuan, asumsi, sintak, sistem sosial, sistem pendukung, dampak pembelajaran, dan dampak pengiring. Penilaian terhadap rancangan pelaksanaan pembelajaran, meliputi rumusan tujuan, materi pembelajaran, langkah-langkah pembelajaran, sistem penilaian, keterkaitan antar unsur pembelajaran, dan pemanfaatannya sebagai pedoman pembelajaran. 
Tabel 1. Gambaran Umum Model Pembelajaran Nondirektif

\begin{tabular}{|c|c|c|}
\hline No. & Aspek-aspek Terkait & Uraian \\
\hline 1. & Orientasi dan tujuan & $\begin{array}{l}\text { Membantu peserta didik mengekspresikan gagasan, perasaan, } \\
\text { dan pola laku yang memungkinkan mereka tumbuh dan } \\
\text { berkembang menjadi pribadi yang baik, efektif, dan percaya } \\
\text { diri. }\end{array}$ \\
\hline 2. & Asumsi & $\begin{array}{l}\text { Peserta didik adalah individu yang memiliki potensi utuh dan } \\
\text { bisa dikembangkan secara optimal, lingkungan merupakan } \\
\text { faktor yang mempengaruhi dan menentukan keberhasilan } \\
\text { peserta didik dalam kegiatan belajar, dan interaksi harmonis } \\
\text { antara guru dengan peserta didik perlu dibangun dalam proses } \\
\text { pembelajaran. }\end{array}$ \\
\hline 3. & Sintaks & $\begin{array}{l}\text { Tahap pertama; menjelaskan situasi atau keadaan yang } \\
\text { memerlukan pertolongan atau pemecahan dengan cara } \\
\text { mendorong peserta didik mengungkapkan perasaan (keresahan, } \\
\text { rasa ketimpangan, dan penasaran) secara bebas. } \\
\text { Tahap kedua; menelusuri masalah dengan cara mendorong } \\
\text { peserta didik menjabarkan (ekspolorasi) dan menetapkan } \\
\text { masalah serta menghargai hasil kerja peserta didik. } \\
\text { Tahap ketiga; mengembangkan wawasan dengan cara } \\
\text { mengajak peserta didik mendiskusikan berbagai masalah dan } \\
\text { menyemangatinya saat berdiskusi. } \\
\text { Tahap keempat; merencanakan dan membuat keputusan } \\
\text { dengan cara mengajak dan membimbing perserta didik mencari } \\
\text { sejumlah alternatif pemecahan masalah. } \\
\text { Tahap kelima; kertepaduan dengan ditandai peserta didik } \\
\text { semakin paham dan keinginan mengembangkan lebih lanjut atas } \\
\text { solusi tindakan yang digunakan untuk memecahkan masalah. }\end{array}$ \\
\hline 4. & Sistem sosial & $\begin{array}{l}\text { Guru berperan sebagai fasilitator atau reflektor. Walaupun } \\
\text { peserta didik memperoleh kebebasan untuk mengekspresikan } \\
\text { gagasan, perasaan, dan tindakan akan tetapi tetap perlu } \\
\text { menjunjung dan memperhatikan kesantuan dalam beraktivitas. }\end{array}$ \\
\hline 5. & Sistem pendukung & $\begin{array}{l}\text { Agar kegiatan pembelajaran non direktif terselenggara secara } \\
\text { efektif diperlukan lingkungan, kultur akademik, sarana dan } \\
\text { prasarana, serta ketersediaan waktu yang mendukung peserta } \\
\text { didik mampu mengekspresikan gagasan, perasaan, dan } \\
\text { tindakannya secara optimal. }\end{array}$ \\
\hline 6. & Dampak pembelajaran & $\begin{array}{l}\text { Meningkatkan komunikasi terpadu, mengembangkan } \\
\text { pemahaman diri dan refleksi, pengembangan diri. }\end{array}$ \\
\hline 7. & Dampak pengiring & $\begin{array}{l}\text { Mengembangkan harga diri, meningkatkan motivasi akademik } \\
\text { dan sosial, dan mengembangkan kapasitas dan prestasi belajar. }\end{array}$ \\
\hline
\end{tabular}

Berdasarkan hasil penilaian ahli pembelajaran dapat dikatakan bahwa pada prinsipnya model pembelajaran non direktif dapat digunakan untuk penanaman nilai-nilai budaya Yogyakarta di sekolah dasar. Namun demikian, masih ada beberapa aspek yang perlu diperhatikan yaitu sebelum model pembelajaran ini diterapkan perlu dilakukan pelatihan terlebih dahulu kepada para guru subjek penelitian dan penilaian aspek afektif perlu menggunakan teknik yang bervariasi sehingga hasilnya benar-benar representatif. Vi- sualisasi model pembelajaran non direktif untuk penanaman nilai-nilai budaya Yogyakarta di sekolah dasar hasil pengembangan dapat dilihat pada Tabel 2.

Selanjutnya, model pembelajaran tersebut dikembangkan dalam bentuk rencana pelaksanaan pembelajaran sebagai pedoman pembelajaran nilai-nilai budaya Yogyakarta seperti terlihat pada Gambar 2. 
Tabel 2. Model Pembelajaran Nondirektif untuk Pembelajaran Budaya Yogyakarta

\begin{tabular}{|c|c|c|}
\hline No. & Aspek-aspek Terkait & Uraian \\
\hline 1. & Orientasi dan tujuan & $\begin{array}{l}\text { Memfasilitasi peserta didik mewujudkan kedaulatan budaya } \\
\text { Yogyakarta dalam kegiatan pembelajaran di sekolah. }\end{array}$ \\
\hline 2. & Asumsi & $\begin{array}{l}\text { Peserta didik adalah mahluk sosial, lingkungan sosial budaya } \\
\text { Yogyakarta mempengaruhi perilaku warga masyarakat } \\
\text { Yogyakarta, dan interaksi guru dengan peserta didik merupakan } \\
\text { alat transformasi nilai-nilai budaya Yogyakarta. }\end{array}$ \\
\hline 3. & Sintaks & $\begin{array}{l}\text { Tahap pertama; pemaparan situasi kritis budaya Yogyakarta } \\
\text { yang terabaikan dengan cara mendorong peserta didik } \\
\text { mengungkapkan bukti-bukti budaya Yogyakarta terabaikan } \\
\text { (nilai-nilai luhur, artefak, dan adat istiadat) secara bebas. } \\
\text { Tahap kedua; menelusuri akar masalah kritis budaya } \\
\text { Yogyakarta dengan cara mendorong peserta didik menjabarkan } \\
\text { (ekspolorasi) dan menetapkan masalah kritis budaya Yogyakarta } \\
\text { serta menghargai hasil kerja peserta didik. } \\
\text { Tahap ketiga; mengembangkan wawasan dengan cara mengajak } \\
\text { peserta didik mendiskusikan berbagai masalah kritis budaya } \\
\text { Yogyakarta dan menyemangatinya saat berdiskusi. } \\
\text { Tahap keempat; mengembangkan sejumlah solusi alternatif dan } \\
\text { memilih yang relevan untuk mewujudkan budaya Yogyakarta } \\
\text { secara kreatif. } \\
\text { Tahap kelima; mengaplikasikan solusi terpilih untuk penanaman } \\
\text { nilai-nilai budaya Yogyakarta secara efektif. }\end{array}$ \\
\hline 4. & Sistem sosial & $\begin{array}{l}\text { Norma, etika, dan moral masyarakat Yogyakarta melingkupi } \\
\text { perilaku peserta didik dalam berinteraksi sehari-hari di keluarga, } \\
\text { sekolah, dan masyarakat. }\end{array}$ \\
\hline 5. & Sistem pendukung & $\begin{array}{l}\text { Agar kegiatan pembelajaran ini terselenggara secara efektif } \\
\text { diperlukan dukungan keluarga, kebijakan pemerintah, dan } \\
\text { suasana kultural di sekolah. }\end{array}$ \\
\hline 6. & Dampak pembelajaran & Berbudaya Yogyakarta sesuai dengan kurikulum yang berlaku. \\
\hline 7. & Dampak pengiring & $\begin{array}{l}\text { Berkepribadian Yogyakarta, kesadaran diri mengenal, } \\
\text { mengapresiasi, aktualisasi diri, dan kreatif terhadap nilai-nilai } \\
\text { budaya Yogyakarta. }\end{array}$ \\
\hline
\end{tabular}

\section{Hasil Uji Coba Model Pembelajaran}

Uji coba terhadap draft awal model pembelajaran nondirektif dirancang guna memfasilitasi peserta didik memahami nilai-nilai budaya Yogyakarta. Tujuan uji coba ini untuk mengembangkan draf model awal yang layak digunakan guru dalam penanaman nilai-nilai budaya Yogyakarta.

Uji coba ini dilakukan dalam tiga kali putaran. Penetapan jumlah putaran ini didasarkan atas kemampuan guru dalam mengimplementasikan model pembelajaran ini sesuai target yang ditetapkan. Setelah melalui putaran ketiga, model pembelajaran yang ditemukan dipandang sudah memadai atau layak digunakan. Perubahan dan modifikasi dilakukan terhadap langkah-langkah pembelajarannya yang dianggap sulit dilakukan guru, terutama yang berkaitan dengan usaha mengarahkan peserta didik dalam menentukan, memilih, dan memutuskan sendiri contoh-contoh nilai budaya Yogyakarta yang ingin dipelajari dan dipahami dalam setiap kali pembelajaran.

Pada tahap pendahuluan, kegiatan utama yang dilakukan adalah penyajian atau deskripsi tentang kondisi atau situasi kritis tentang semakin lunturnya nilai-nilai budaya Yogyakarta di kalangan peserta didik. Pada tahap kegiatan inti dilakukan modifikasi terhadap fase eksplorasi, pengembangan sejumlah solusi, pemilihan solusi terbaik dari sejumlah solusi, dan aplikasi budaya yang relevan dan efektif. Pada fase eksplorasi, peserta didik masih membutuhkan arahan dari guru dalam mencari informasi terkait berbagai kasus krisis budaya. Fase pengembangan sejumlah solusi dan pemilihan solusi terbaik dari sejumlah solusi, para peserta didik sudah bisa berlatih berpendapat untuk menentukan solusi terbaik dalam 


\section{RENCANA PELAKSANAAN PEMBELAJARAN}

$\begin{array}{ll}\text { Sekolah Dasar } & : \\ \text { Kelas/semester } & : \\ \text { Tema } & : \\ \text { Sub-tema } & : \\ \text { Muatan pelajaran } & : \\ \text { Alokasi waktu } & :\end{array}$

A. Kompetensi Inti (KI)

(memuat nilai-nilai budaya Yogyakarta yang tertera dalam rumusan kompetensi minimal yang harus dikuasai peserta didik berdasarkan kurikulum 2013)

B. Kompetensi Dasar dan Indikator

1. Kompetensi dasar (memuat rincian nilai-nilai budaya Yogyakarta yang harus dikuasai peserta didik berdasarkan rumusan kompetensi inti)

2. Indikator (bukti penguasaan nilai-nilai budaya Yogyakarta dalam kegiatan pembelajaran sehari-hari)

C. Materi Pembelajaran (Uraian materi untuk mewujudkan pencapaian kompetensi dasar)

D. Tujuan Pembelajaran : (Perubahan perilaku peserta didik setelah mengikuti pembelajaran sesuai rumusan tujuan pembelajaran

E. Metode dan Pendekatan : (Metode pembelajaran non direktif untuk pembelajaran budaya Yogyakarta)

F. Langkah-langkah Pembelajaran

\begin{tabular}{|l|l|l|}
\hline Kegiatan & Deskripsi kegiatan & Alokasi waktu \\
\hline Pendahuluan & $\begin{array}{l}\text { Menjelaskan situasi-situasi kritis budaya } \\
\text { Yogyakarta sesuai kurikulum yang berlaku }\end{array}$ & $10 \%$ \\
\hline Inti & $\begin{aligned} \text { a. } \text { Menelusuri masalah krisis budaya } \\
\quad \text { Yogyakarta }\end{aligned}$ & $80 \%$ \\
& $\begin{aligned} \text { b. } \text { Mengembangkan wawasan } \\
\text { c. Merencanakan dan membuat } \\
\text { keputusan }\end{aligned}$ & \\
& $\begin{array}{l}\text { Kertepaduan, membutuhkan berbagai } \\
\text { sumber dan media pembelajaran } \\
\text { yang bervariasi }\end{array}$ & \\
\hline Penutup & Kesimpulan dan tindak lanjut & \\
\hline
\end{tabular}

G. Teknik Penilaian

1. Aspek-aspek yang dinilai :

2. Rubrik

3. Prosedur

H. Media, Alat, dan Sumber Belajar

Gambar 2. Rencana Pelaksanaan Pembelajaran Nilai-nilai Budaya Yogyakarta

menjawab masalah kritis budaya. Fase aplikasi, peserta didik membutuhkan berbagai sumber dan media pembelajaran yang relevan. Selanjutnya, pada tahap penutup memuat kegiatan penyimpulan dan tindak lanjut bagi peserta didik untuk menyongsong kegiatan pembelajaran berikutnya. 


\section{Pembahasan}

Secara substansial, model pembelajaran non direktif untuk penanaman nilai-nilai budaya Yogyakarta di sekolah dasar sangat relevan digunakan. Peserta didik difasilitasi dan dikondisikan untuk mencari sendiri sejumlah jawaban atas berbagai masalah yang berkaitan dengan krisis budaya, khususnya budaya Yogyakarta. Pembelajaran ini menekankan pada pengembangan kemandirian (pikiran dan perasaan) peserta didik dalam mempelajari berbagai nilai-nilai budaya Yogyakarta, yang memuat aspek-aspek adat istiadat, artefak, dan nilai-nilai luhur masyarakat.

Ciri khas dari model pembelajaran ini adalah adanya langkah pembelajaran yang memberi kebebasan berkreasi memilih dan menetapkan solusi atas masalah kritis budaya Yogyakarta secara mandiri. Peserta didik bukan diarahkan untuk memilih dan menetapkan satu solusi mengatasi krisis budaya Yogyakarta, tetapi mereka didampingi memilih dan menetapkan solusi terbaik untuk memcahkan krisis budaya Yogyakarta sesuai rumusan kompetensi yang ada di kurikuluam yang berlaku. Joyce dan Weil (2004:271) menyatakan "the nondirective teaching model focuses on facilitating learning. The environment is organized to help students attain greater personal integration, effectiveness, and realistic sefl-apprisal". Dengan penggunaan model pembelajaran ini, diharapkan peserta didik mampu mengembangkan kepribadiannya secara utuh dan mandiri melalui penataan lingkungan belajar yang kondusif di sekitar peserta didik.

Jika dibandingkan dengan model pembelajaran lainnya, model pembelajaran memiliki keunggulan dalam memfalisitasi peserta didik dalam memahami, memilih, dan menerapkan ide-ide baru untuk kepentingan peserta dalam menghadapi berbagai permasalahan yang sedang dihadapi. Oleh karena itu, guru harus menghormati kemampun peserta didik dalam setiap aktivitas pembelajarnya, memahami karakteristik pemikiran peserta didik, dan menciptakan suasana komunikasi yang bernuansa empati. Guru juga perlu memberi komentar yang bersifat reflektif untuk membangkitkan semangat peserta didik agar semakin giat dalam menemukan ide-ide baru. Hal ini sejalan dengan pendapat Sinaga (2016:357) bahwa sebuah proses belajar, selain menuntut kreativitas guru juga dibutuhkan kesiapan siswa dalam pembelajaran.
Aplikasi model pembelajaran non direktif untuk penanaman nilai-nilai budaya Yogyakarta di sekolah dasar sangat relevan dengan kebijakan Pemerintah Daerah Istimewa Yogyakarta. Di dalam Peraturan Gubernur Daerah Istimewa Yogyakarta Nomor 66 Tahun 2013 tentang Kurikulum Pendidikan Berbasis Budaya, antara lain dinyatakan bahwa implementasi kurikulum pendidikan berbasis budaya dapat dilakukan dengan berbagai pola yaitu terintegrasi dalam setiap mata pelajaran, pengembangan diri dalam bentuk kegiatan ekstra kurikuler, monolitik yaitu sebagai materi ajar sendiri, dan pengembangan budaya satuan pendidikan berbasis budaya khas Yogyakarta dalam bentuk perilaku sehari-hari secara individual dan organisasional. Wuryandani dkk (2016:208) menyatakan Melalui bekal nilai karakter yang baik tersebut diharapkan mereka lebih mudah untuk berinteraksi dan beradaptasi dengan lingkungan sekitarnya. Di sini, model pembelajaran non direktif digunakan dalam pola implementasi "integrasi dalam setiap mata pelajaran".

Berdasarkan temuan penelitian bahwa guru masih merasa kesulitan dalam mengkondisikan suasana pembelajaran yang memungkinkan peserta didik berani dengan sendiri mengungkapkan ide-ide baru untuk memecahkan masalah belajar yang sedang dihadapi dapat dianggap sebagai situasi yang menarik dikaji. Salah satu penyebabnya adalah kurang atau belum optimalnya peserta didik diajak berpikir secara kreatif dalam pembelajaran, sehingga ketika mereka dikenalkan dengan metode pembelajaran baru yang lebih aktif dan kreatif mereka merasa kesulitan dalam mengungkapkan ide-ide baru secara spontan.

Untuk memecahkan persoalan ini adalah mengoptimalkan peran guru dalam membimbing peserta didik pada saat peserta memperoleh tugas mengemukakan gagasan-gagasan baru. Dengan ketekunan, kesabaran, dan keuletan guru dalam membantu peserta didik mengemukakan gagasangagasannya dimungkinkan peserta didik akan muncul banyak gagasan baru dari peserta didik untuk kepentingan belajarnya. Joyce dan Weil (2004:271) mengatakan "in being accepting and nonpunitive, the teacher indirectly communicates to the students that all thoughts and feelings are acceptable".

Selanjutnya, agar model pembelajaran non direktif ini lebih efektif dalam implementasinya diperlukan adanya penggunaan sumber belajar dan media pembelajaran yang bervariasi sesuai 
karakteristik nilai-nilai budaya Yogyakarta yang sedang dipelajari (nilai-nilai luhur, artefak, dan adat istiadat). Salah satu alasannya adalah sumber belajar dan media pembelajaran dapat memudahkan peserta didik dalam kegiatan pembelajaran. Dengan menggunakan sumber belajar dan media pembelajaran yang efektif para peserta didik dapat memperoleh kemudahan dan kejelasan pada saat menerima pesan-pesan pembelajaran menjadi pengalaman belajar. Iswardhani dan Djukri (2015:151) menyatakan bahwa( pemilihan dan penggunaan sumber belajar yang sesuai dengan karakteristik pelajaran dan gaya belajar siswa dapat meningkatkan prestasi belajar siswa.

\section{SIMPULAN}

Ada sejumlah nilai-nilai budaya Yogyakarta yang dapat diintegrasikan dalam materi ajar setiap mata kuliah yang relevan sebagaimana yang tertera dalam kurikulum yang berlaku di sekolah dasar, yang meliputi nilai-nilai luhur, artefak, dan adat istiadat atau kebiasaan yang berlaku di masyarakat Yogyakarta. Model pembelajaran yang relevan digunakan untuk penanaman nilainilai budaya Yogyakarta adalah model pembelajaran non direktif dari Carl Rogers. Pengembangan model pembelajaran non direktif ini dilakukan untuk mengoptimalkan dan mengefektifkan proses transmisi dan transformasi nilai-nilai budaya Yogyakarta kepada peserta didik di sekolah dasar, baik yang berkaitan dengan aspek-aspek utama pembelajaran maupun langkah-langkah pembelajarannya. Hasil ujicoba model pembelajaran non direktif untuk optimalisasi dan efektivitas pembelajaran nilai-nilai menghendaki adanya modifikasi dalam dua hal. Pertama, guru diharapkan mendampingi secara sungguh-sungguh dalam fase eksplorasi karena fase ini penting bagi peserta didik dalam pengungkapan gagasan baru. Kedua, penggunaan sumber belajar dan media pembelajaran pada fase aplikasi sehingga peserta didik mampu melaksanakan tugas belajar secara benar dan nyata.

Berdasarkan temuan ini disarankan agar guru diberi pelatihan secara intensif sebelum pelaksanaan model pembelajaran yang akan diujicobakan. Pemahaman dan ketrampilan guru yang memadai dalam penggunaan model pembelajaran sangat berpengaruh terhadap mutu pembelajaran. Penyediaan sumber belajar dan media pembelajaran sangat diperlukan dalam proses pembelajaran nilai-nilai budaya Yogyakarta, terutama untuk kepentingan konkritisasi konsep yang sedang diajarkan. Kedekatan emosial antara guru dengan peserta didik perlu dibangun untuk memaksimalkan proses internalisasi pengalaman belajar kepada peserta didik dalam pembelajaran.

\section{UCAPAN TERIMA KASIH}

Artikel ini merupakan hasil penelitian tentang pengembangan pembelajaran nilai-nilai budaya Yogyakarta di sekolah dasar. Penulis menyampaikan terimakasih kepada Direktur Riset dan Pengabdian kepada Masyarakat Ditjen Penguatan Riset dan Pengembangan Kementerian Riset, Teknologi, dan Pendidikan Tinggi yang telah mendanai penelitian ini. Ucapan terima kasih juga disampaikan kepada Dewan Redaktur Jurnal Cakrawala Pendidikan Lembaga Pengembangan dan Penjaminan Mutu Pendidikan Universitas Negeri Yogyakarta.

\section{DAFTAR PUSTAKA}

Borg, W.R \& Gall, M.D. 1983. Edacational Research: An Introduction. New York: Longman.

Ekowarni, Endang. 2010. "Pengembangan Nilainilai Luhur Budi Pekerti sebagai Karakter Bangsa”. Diambil dari http://belanegarari. wordpress.com/2009/08/25/pengembangan-nilai-nilai-luhur-budi-pekerti-sebagaikarakter-bangsa, Pada tanggal tanggal 26 Maret 2010.

Iswardhani, Nunik dan Djukri. 2015. "Pengaruh Penggunaan Limbah Tapioka sebagai Sumber Belajar terhadap Motivasi dan Hasil Belajar Siswa". Cakrawala Pendidikan, Th. XXXIV, No. 1.

Joyce, Bruce \& Weil, Marsha. 2004. Models of Teaching. Boston: Pearson.

Peraturan Gubernur Daerah Istimewa Yogyakarta Nomer 66 Tahun 2013 tentang Kurikulum Berbasis Budaya.

Peraturan Pemerintah Daerah Istimewa Yogyakarta Nomer 5 tahun 2011 tentang Pengelolaan dan Penyelenggaraan Pendidikan Berbasis Budaya. 
Sinaga, Dearlina. 2016. "Penerapan Model Students Teams Achievement Division untuk Meningkatkan Hasil Belajar dan Kreativitas Belajar Ekonomi”. Cakrawala Pendidikan. Th. XXXV. No. 3.

Sanjaya, Wina. 2005. Pembelajaran dalam Implementasi Kurikulum Berbasis Kompetensi. Jakarta: Prenada Media.
Wuryandani, Wuri, dkk. 2016. "Implementasi Pendidikan Karakter Kemandirian di Muhammadiyah Boarding School". Cakrawala Pendidikan, Juni 2016, Th. XXXV, No. 2. 